\title{
Diazoxide in treatment of primary pulmonary hypertension
}

\author{
S. W. S. WANG, J. E. F. POHL, D. J. ROWLANDS, AND E. G. WADE \\ From the Department of Cardiology, Manchester Royal Infirmary
}

SUMMARY Three patients with primary pulmonary hypertension and one man with suspected thromboembolic pulmonary hypertension were given up to $300 \mathrm{mg}$ diazoxide by injection into the pulmonary artery. The three patients with primary pulmonary hypertension responded with a fall in total pulmonary resistance and a rise in cardiac output. The patient with suspected thromboembolic pulmonary hypertension did not respond. Haemodynamic and clinical improvement was maintained by oral diazoxide in two of the responders, and in one the prognosis appeared to be greatly improved.

Diazoxide is a thiazide derivative which is a potent vasodilator but not a diuretic. It has been used for treating systemic hypertension (Pohl and Thurston, 1971; Pohl et al., 1972; Moser, 1974; Koch-Weser, 1976), but there are no reports of its use in the treatment of primary pulmonary hypertension. In this paper we report our experience with the drug in the treatment of 3 patients with primary pulmonary hypertension and a fourth suffering from pulmonary hypertension of uncertain aetiology. All the patients attended the Department of Cardiology, the Manchester Royal Infirmary. Neither of the women had used oral contraceptives or appetite suppressants.

\section{Procedure}

In all cases the effect of injecting diazoxide into the pulmonary artery was assessed first. A catheter was placed in the main trunk of the pulmonary artery and a systemic arterial line was inserted into a brachial artery. Pulmonary and systemic arterial pressures were measured by Statham P20 transducers. Cardiac output was estimated by the dye injection technique using cardiogreen and a Waters densitometer. The cardiac output was calculated using the Hamilton equation and the central blood volume contained between the injection site (pulmonary trunk) and the sampling site (brachial artery) was also calculated. All measurements were made in duplicate. Serum diazoxide concentration was measured by the method of Symchowicz et al. (1967).

The procedure was as follows: after basal measurements, $45 \mathrm{mg}$ diazoxide was injected rapidly into the pulmonary artery. After allowing time for stabilisation of pulse rate and pressures, usually 5 minutes, all measurements were repeated and blood taken for serum diazoxide concentration. The process was then repeated after successive injections of 90,180 , and $300 \mathrm{mg}$ diazoxide. The 3 patients responding favourably in the acute experiment were given oral diazoxide in doses of 400 to $600 \mathrm{mg}$ daily, sufficient to maintain serum concentrations between 75 and $100 \mu \mathrm{g} / \mathrm{ml}$. The fourth patient who did not respond was not so treated.

Two of the 3 patients on oral diazoxide were restudied after periods of treatment of 17 to 33 months.

\section{Patients}

\section{CASE 1}

A 26-year-old married woman had had progressive dyspnoea for 5 months, beginning 2 years after the uncomplicated birth of her second child. Examina- $N$ tion showed signs of severe pulmonary arterial $N$ hypertension, confirmed by catheterisation, for which no cause was found. Injection of diazoxidece caused a fall in total pulmonary resistance from 26 Ф to 12 units, a rise in cardiac output from 2.4 to $\stackrel{?}{+}$ $4.81 / \mathrm{min}$, and slight fall in pulmonary arterial pressure from $101 / 55$ to $93 / 53 \mathrm{mmHg}$. At first she $\frac{\mathrm{O}^{\circ}}{\mathrm{D}}$ refused oral therapy but later, after clinical de- $\stackrel{\mathbb{Q}}{?}$ terioration, she assented, and was started on $200 \mathrm{mg} \stackrel{\mathbb{Q}}{\mathcal{D}}$ t.d.s. Her condition steadily worsened and she diedত̄ a few weeks after starting treatment. She was never $O$ fit enough to restudy and a necropsy was refused. 
CASE 2

A 34-year-old man had suffered from dyspnoea, light-headedness, and exertional syncope for six years. On examination there was evidence of severe pulmonary arterial hypertension but no other abnormality. For 10 years he had been treated with anticoagulant, digitalis, and diuretic, but his symptoms worsened and he developed severe angina. He was then assessed for diazoxide therapy. Injection of the drug caused a fall in total pulmonary resistance from 23 to 12 units, a rise in cardiac output from 3.3 to $5.31 / \mathrm{min}$, and a fall in pulmonary arterial pressure from $109 / 60$ to $90 / 49$ mmHg. Oral diazoxide treatment was started, with $400 \mathrm{mg}$ daily, the anticoagulant was continued, and he improved. His exertional syncope ceased, his breathlessness improved, and his angina decreased. He was restudied after 17 months of treatment; the pulmonary resistance then was 14 units, the cardiac output $5.0 \mathrm{l} / \mathrm{min}$, and the pulmonary arterial pressure was $110 / 34 \mathrm{mmHg}$. Three months later he began to deteriorate, his angina worsened, and he died outside hospital 2 years after the start of diazoxide treatment.

\section{CASE 3}

A 39-year-old woman had experienced a syncopal attack during her first pregnancy 17 years previously. Three years later, with her second and last pregnancy, exertional syncope again occurred and persisted. When first seen she could walk no more than 50 yards at a slow pace. Clinical examination showed only the signs of severe pulmonary hypertension without obvious cause. Injection of diazoxide caused a fall in total pulmonary resistance from 26 to 12 units, a rise in cardiac output from 2.8 to $4.91 / \mathrm{min}$, and a reduction in pulmonary arterial pressure from $110 / 54$ to $79 / 49 \mathrm{mmHg}$. Oral treatment was started initially with $400 \mathrm{mg}$ daily, and later increased to $600 \mathrm{mg}$ daily. In this case we were able to make the fairly precise observation that an improvement in exercise tolerance occurred when the serum diazoxide concentration was above $70 \mu \mathrm{g} / \mathrm{ml}$; below this, her symptoms worsened. Twenty-eight months after starting treatment she was able to walk briskly without symptoms, was working full time, and was able to go dancing. The pulmonary resistance was now 6 units, the cardiac output $7.91 / \mathrm{min}$, and the pulmonary arterial pressures 75/40 (mean $50 \mathrm{mmHg}$.) She remains well, and further study 6 months later gave similar results.

\section{CASE 4}

A 49-year-old man had had an operation for varicose veins 18 months previously. A month later he complained of abdominal and chest pain with ankle swelling. He was admitted to another hospital in heart failure. Examination disclosed evidence of pulmonary arterial hypertension and congestive heart failure. Thromboembolic pulmonary hypertension was suspected and a lung scan was equivocal showing patchy uptake.

Diazoxide by injection did not bring about a fall in total pulmonary resistance. Initially this was 23 units, the cardiac output $2.8 \mathrm{l} / \mathrm{min}$, and the pulmonary artery pressure $124 / 34 \mathrm{mmHg}$. After 300 mg diazoxide the cardiac output had risen to 3.8 $1 / \mathrm{min}$, the pulmonary resistance was unchanged, and the pulmonary artery pressure had risen to $164 / 52 \mathrm{mmHg}$. He was, therefore, treated with

Table Haemodynamic changes after diazoxide

\begin{tabular}{|c|c|c|c|c|c|c|c|c|c|c|c|c|}
\hline \multirow[t]{2}{*}{$\begin{array}{l}\text { Case } \\
\text { No. }\end{array}$} & & \multirow{2}{*}{$\begin{array}{l}\text { Heart } \\
\text { rate } \\
\text { (beat } / \mathrm{min} \text { ) }\end{array}$} & \multirow{2}{*}{$\begin{array}{l}\text { Cardiac } \\
\text { output } \\
\text { (l/min) }\end{array}$} & \multicolumn{3}{|c|}{$\begin{array}{l}\text { Pulmonary arterial } \\
\text { pressure }(\mathrm{mm} H \mathrm{~g})\end{array}$} & \multirow{2}{*}{$\begin{array}{l}\text { Total } \\
\text { pulmonary } \\
\text {-resistance } \\
\text { (units) }\end{array}$} & \multirow{2}{*}{$\begin{array}{l}\text { Central } \\
\text { blood } \\
\text { vol }(\mathrm{ml})\end{array}$} & \multicolumn{3}{|c|}{$\begin{array}{l}\text { Systemic arterial } \\
\text { pressure }(\mathrm{mmHg})\end{array}$} & \multirow{2}{*}{$\begin{array}{l}\text { Total } \\
\text { systemic } \\
\text { resistance } \\
\text { (units) }\end{array}$} \\
\hline & & & & Systolic & Diastolic & Mean & & & Systolic & Diastolic & Mean & \\
\hline \multirow{3}{*}{1} & Basal & 107 & $2 \cdot 4$ & 101 & 55 & 71 & 26 & 920 & 118 & 81 & 92 & 31 \\
\hline & Pulmonary & & & & & & & & & & & \\
\hline & artery injection * & 110 & $4 \cdot 8$ & 93 & 53 & 67 & 12 & 1520 & 93 & 57 & 67 & 10 \\
\hline \multirow[t]{4}{*}{2} & $\begin{array}{l}\text { Basal } \\
\text { Pulmonary }\end{array}$ & 78 & $3 \cdot 3$ & 109 & 60 & 76 & 23 & 1375 & 166 & 87 & 113 & 34 \\
\hline & artery injection * & $\begin{array}{l}106 \\
107\end{array}$ & $5 \cdot 3$ & 90 & 49 & 63 & 12 & 1678 & 140 & 54 & 83 & 16 \\
\hline & $\begin{array}{l}17 \text { months oral } \\
\text { Basal }\end{array}$ & $\begin{array}{r}107 \\
97\end{array}$ & $\begin{array}{l}5 \cdot 0 \\
2 \cdot 8\end{array}$ & $\begin{array}{l}110 \\
110\end{array}$ & $\begin{array}{l}34 \\
54\end{array}$ & $\begin{array}{l}68 \\
73\end{array}$ & $\begin{array}{l}14 \\
26\end{array}$ & 887 & $\begin{array}{l}125 \\
113\end{array}$ & $\begin{array}{l}80 \\
70\end{array}$ & $\begin{array}{l}95 \\
84\end{array}$ & $\begin{array}{l}19 \\
30\end{array}$ \\
\hline & $\begin{array}{l}\text { Pulmonary } \\
\text { artery injection }\end{array}$ & & & & & & & & & & & \\
\hline \multirow{3}{*}{3} & $\begin{array}{l}\text { artery injection* } \\
27 \text { months oral }\end{array}$ & $\begin{array}{r}138 \\
90\end{array}$ & $4 \cdot 9$ & 79 & 49 & 59 & 12 & 1143 & 107 & 57 & 72 & 15 \\
\hline & $\begin{array}{l}27 \text { months oral } \\
33 \text { months oral }\end{array}$ & $\begin{array}{l}90 \\
77\end{array}$ & $7 \cdot 9$ & 75 & 40 & 50 & 6 & & 130 & 80 & 98 & 12 \\
\hline & $\begin{array}{l}33 \text { months oral } \\
\text { Basal }\end{array}$ & $\begin{array}{l}77 \\
65\end{array}$ & $5 \cdot 8$ & $\begin{array}{r}70 \\
124\end{array}$ & $\begin{array}{l}30 \\
34\end{array}$ & $\begin{array}{l}45 \\
64\end{array}$ & $\begin{array}{r}8 \\
23\end{array}$ & & 110 & 68 & 82 & 14 \\
\hline \multirow[t]{2}{*}{4} & $\begin{array}{l}\text { Basal } \\
\text { Pulmonary }\end{array}$ & & 20 & & & & & 840 & 128 & 60 & 83 & 30 \\
\hline & artery injection $\star$ & 105 & $3 \cdot 8$ & 164 & 52 & 89 & 23 & 950 & 132 & 64 & 87 & 23 \\
\hline
\end{tabular}

*Total injected dose $515 \mathrm{mg}$. 
anticoagulant but not given oral diazoxide therapy. His condition 12 months later is virtually unchanged.

The haemodynamic changes, including the systemic arterial pressures and resistances, are shown in the Table.

\section{Discussion}

Diazoxide, injected directly into the pulmonary artery in three cases of primary pulmonary hypertension, caused a fall in pulmonary resistance and a rise in cardiac output. The drug is not detoxicated in the lungs and, therefore, it produces a similar fall in systemic arterial pressure. Because of the possibility of causing a precipitate drop in systemic arterial pressure a carefully controlled dose schedule was used, but in none of our patients was there any cause for alarm.

The drug may act on the pulmonary circulation in one of two ways: direct vasodilatation of the small pulmonary resistance vessels or indirectly through a reduction in pulmonary blood volume. It seems unlikely that the action observed was achieved indirectly for the following reasons: firstly, direct measurement invariably showed a rise in central blood volume after injection of diazoxide, not a fall; secondly, there is evidence that diazoxide does not affect capacitance vessels and in this respect differs from both nitroglycerin and sodium nitroprusside (F. J. Conway, 1977, personal communication). It seems reasonable, therefore, to assume that the action is a direct one.

We believe that the rise in cardiac output is an important feature of the action of the drug and the principal reason for the improvement in symptoms in two patients. The increase in cardiac output to within the normal range may be seen as a physiological response to the reduction in pulmonary vascular resistance and hence the right ventricular afterload, but diazoxide may also have a direct effect on the heart as it is also observed to increase the heart rate.

Oral diazoxide appeared to have a beneficial effect on the symptoms in case 2 and on the symptoms, signs, and natural history in case 3 . In case 3 also there appeared to be a critical serum diazoxide concentration of between 75 and $100 \mu \mathrm{g} / \mathrm{ml}$, below which symptoms were not relieved. We do not know whether this critical level may differ considerably from case to case; if so, the disappointing results in other cases may reflect inadequate dosage and this possibility requires further investigation. In case 4 failure to respond to an injection of diazoxide may have an alternative explanation. This man was considered to be a possible though unproven example of thromboembolic pulmonary hypertension and, therefore, vasoconstriction may be a less important factor in maintaining the high pulmonary vascular resistance than irreversible pulmonary vascular obstruction.

Systemic hypotension did not prove to be a problem. Though oral diazoxide caused a fall in systemic resistance this was offset by the rise in cardiac output so that the systemic arterial pressure was maintained at near to the original level in all cases.

We feel that the improvement in the anticipated natural history of the disease in case 3 can be attributed to the oral diazoxide therapy. Spontaneous regression of primary pulmonary hypertension is extremely rare; Bourdillon and Oakley (1976) have reported 1 case and we have encountered 1 case in a series of over 50 , but we know of no other reported examples. Further studies on the effect of diazoxide in the management of this lethal disease appear justified.

\section{References}

Bourdillon, P. D. V., and Oakley, C. M. (1976). Regression of primary pulmonary hypertension. British Heart fournal, 38, 264-270.

Koch-Weser, J. (1976). Drug therapy: diazoxide. New England fournal of Medicine, 294, 1271-1273.

Moser, M. (1974). Diazoxide-an effective vasodilator in accelerated hypertension. American Heart fournal, 87, 791-795.

Pohl, J. E. F., and Thurston, H. (1971). Use of diazoxide in hypertension with renal failure. British Medical fournal, 4, 142-145.

Pohl, J. E. F., Thurston, H., Davis, D., and Morgan, M. Y. (1972). Successful use of oral diazoxide in the treatment of severe toxaemia of pregnancy. British Medical Fournal, 2, 568-570.

Symchowicz, S., Winston, L., Black, J., Smith, M., Calesnick, B., and Tabachnick, I. A. A. (1967). Diazoxide blood levels in man. Fournal of Pharmaceutical Sciences, 56, 912-914.

Requests for reprints to Dr E. G. Wade, Department of Cardiology, The Royal Infirmary, Manchester M13 9WL. 